Research Article

\title{
Antioxidant and Cytotoxicity Activities of the Fermentation Extract of the Endophytic Fungi from the Marine Biota of Colt Coral
}

\author{
Dede Sukandar ${ }^{1 *}$, Nina Artanti², Ika Restu Purwanti ${ }^{1}$, Tarso Rudiana ${ }^{1,3}$, Fitriyanti ${ }^{1}$
}

${ }^{1}$ Study Program of Chemistry, Faculty of Science and Technology, Universitas Islam Negeri Syarif Hidayatullah, South Tangerang, Indonesia, 15412

${ }^{2}$ Research Center for Chemistry, Indonesian Institute of Sciences (LIPI), South Tangerang, Indonesia, 15314

3 Study Program of Chemistry, Faculty of Science, Pharmacy and Health, Universitas Mathla'ul Anwar, Pandeglang, Indonesia, 42273

\section{ARTICLE INFO \\ ABSTRACT}

\section{Article History}

Accepted 22 March 2021

Revised 9 September 2021

Available online 14 January 2022

* Author Corresponding:

sukandarkimia@uinjkt.ac.id

\begin{abstract}
Indonesia has the largest and most biodiverse coral reef in the world. Colt coral has not been studied and explored especially endophytic fungi associated with the coral. Endophytic fungi are highly potential for the production of antioxidant and anticancer compounds. This research aimed to study the antioxidant and cytotoxic activities of fermentation extract from endophytic fungi from colt coral. Filtrate and mycelium extracts were obtained from static and shake fermentations of isolate SKF 15. Antioxidant and cytotoxic assays were conducted by free radical scavenger 1,1-diphenyl-2-picrylhydrazyl (DPPH) and AlamarBlue methods, respectively. The result showed that FD extract provided the highest antioxidant activity with inhibition of $49.36 \%$ at $200 \mathrm{ppm}$ of DPPH. Variation of fermentation time (3-21 days) demonstrated the highest activity with inhibition of $66.97 \%$ for antioxidant assay ( 7 days) and $81.13 \%$ for cytotoxic assay ( 3 days). FTIR analysis presented the existence of hydroxyl groups $\mathrm{O}-\mathrm{H}\left(3452.58 \mathrm{~cm}^{-1}\right), \mathrm{C}=\mathrm{C}$ groups $\left(1668.43 \mathrm{~cm}^{-1}\right)$; C-O hydroxyl group (1230.58 $\left.\mathrm{cm}^{-1}\right)$, and C-H sp ${ }^{3}$ groups $(2941.44$ $\left.\mathrm{cm}^{-1}\right)$. Based on LC-MS analysis, FD extract has a mass of $\mathrm{m} / \mathrm{z} 305.63,[\mathrm{M}+\mathrm{H}]^{+}$, predicted as dihydroquercetin $\left(\mathrm{C}_{15} \mathrm{H}_{24} \mathrm{O}_{7}\right)$.
\end{abstract}

Keywords: Antioxidant assay, cytotoxic assay, endophytic fungi, colt coral, DPPH method, AlamarBlue method

\section{Introduction}

Antioxidants are compounds capable of capturing free radicals. Free radicals impact the pathogenesis of some diseases in humans, such as arteriosclerosis, cancer, diabetes mellitus, liver damage, inflammation, skin tissue damage, coronary heart, and arthritis [1]. The use of synthetic antioxidants to prevent free radical damage has been reported to result in toxic side effects that require a search for new sources of antioxidants from the wild [2]. One of the many natural ingredients that have high antioxidant activity is the polyphenolic group compounds found as secondary metabolite compounds from plants and fungi [3].

Fungi is one of the promising biotechnology objects in the fermentation process that can produce secondary metabolite compounds [4]. The fermentation process of fungi can be done by the shake and static methods. Differences in the fermentation method are due to the ability of fungi to produce different secondary metabolites [5]. Fungi filament has secondary metabolite compounds that can be utilized as antibiotics and other pharmacological activities such as anticancer, antitumor, and antioxidants [6]. 
The endophytic caps of the marine biota of colt coral were determined the antioxidant and anticancer activities. One example of endophytic utilization was conducted by Putrie et al. [5] that identified Aspergillus sp. isolated from colt coral marine biota with shake fermentation method had the highest antioxidant activity of $71.98 \%$. Artanti et al. [7] examined endophytic shell from Taxus sumatrana, which has antioxidant activity using a mold with static fermentation method with the highest antioxidant activity of $79.5 \%$ for mycelium and $18.2 \%$ for filtrate. The above research concluded that the fermentation treatment affects their bioactivity. Fungi are selected as a source of bioactive compounds because it is easier to handle [8].

\section{Materials and Methods}

\subsection{Materials}

The materials used for this research included Potato Dextrose Agar (Difco TM), Potato Dextrose Broth (Difco MP03500G), Dulbecco's Modified Eagle Media (DMEM), FBS, PBS, trypsin-EDTA solution, MCF-7 culture cells (cell culture preparation of the LIPI Biology Research Center). Other chemicals used were ethyl acetate (Merck), DPPH methanol (1,1 -diphenyl-2-picrylhydrazil) (Sigma), sulfuric acid $\left(\mathrm{H}_{2} \mathrm{SO}_{4}\right)$ (Merck), TLC silica gel $60 \mathrm{~F}_{254}$, and distilled water. SKF 15 isolated from colt coral was obtained from Pameungpeuk sea, Garut, West Java.

\subsection{Preparation of Regeneration Media}

Dextrose Agar (PDA) was used for the fungi regeneration medium. PDA of $3.9 \mathrm{~g}$ was added $100 \mathrm{~mL}$ of distilled water in $250 \mathrm{~mL}$ erlenmeyer. The medium material was mixed using a stirrer until the color of the medium was clear, then sterilized using an autoclave (Yamato SM-310) at $121^{\circ} \mathrm{C}$ with $1 \mathrm{~atm}$. After the temperature and pressure drop, the media was removed and placed into the laminar (ESCO, Singapore). The medium was poured into a sterile petri dish, then the medium was cold and hardened in 10 minutes [9].

\subsection{Preparation of a Stock Culture and Working Culture (Starter)}

A stock culture was prepared by inoculating endophytic fungal colonies into ten petri dishes. The colonies were separated from the starting isolates and planted on a PDA medium. The media was incubated at $37^{\circ} \mathrm{C}$. The stock culture was stored in a refrigerator. Working culture (starter) was done by inoculating the colony with ose method. Each autoclaved medium was inoculated with 3 endophytic fungi and grown in a $50 \mathrm{~mL}$ Potato Dextrose Broth (PDB) medium, then fermented using the static and shake fermentation methods at $37^{\circ} \mathrm{C}$ for 10 days [9].

\subsection{Fermentation of Endophytic Fungi}

Three endophytic fungi were inoculated in a $50 \mathrm{~mL}$ PDB medium, and then the culture was fermented by a static and shake treatment at $37^{\circ} \mathrm{C}$ for 10 days [10].

\subsection{Extraction of Fungal Metabolite}

After fermentation, the culture was separated between the filtrate and mycelium. Each filtrate and mycelium from static and shake fermentations were stirred at $20 \mathrm{rpm}$ for 30 minutes using ethyl acetate solvent. The mixture was separated with a separation funnel, and the fungal extract was evaporated at $40^{\circ} \mathrm{C}$ to obtain a concentrated extract [10]. Four extracts were obtained from this step, namely, FK extract (from filtrate with shake fermentation), MK extract (from mycelium with shake fermentation), FD extract (from filtrate with static fermentation), and MD extract (from mycelium with static fermentation).

\subsection{Antioxidant Assay of Fungal Extract}

DPPH free radical activity was performed following Chen and Yeng [11] with a slight modification. Two hundred micrograms per milliliter sample (fungal extract) were mixed with $1 \mathrm{~mL}$ of a methanol solution containing free radical of DPPH with $1 \mathrm{mM}$ concentration. Then, the mixture was shaken and incubated for 30 minutes in dark condition at room temperature. Absorbance was measured at $517 \mathrm{~nm}$ wavelength using UV-Vis Shimadzu UV mini 1240 with two replications. Quercetin was used as a positive control. The percentage of inhibition was calculated following Equation 1.

$$
\text { Inhibition }(\%)=\frac{\text { Absorbance of blank }- \text { Absorbance of sample }}{\text { Absorbance of blank }} \times 100
$$

\subsection{Autographic Assay using Thin Layer Chromatography (TLC)}

The extract obtained from the filtrate with static fermentation (FD extract) of $1 \mathrm{mg}$ was dissolved with $10 \mathrm{~mL}$ of methanol $96 \%$. The sample and quercetin (positive control) were spotted on the TLC plate. The plate was placed in a chamber containing a set up mobile phase (chloroform : methanol with 10:1 ratio). The elusion process was finished and the plate 
was dried. The chromatogram was sprayed using $0.02 \%(w / v)$ DPPH solution (fresh solution). Spots on TLC were observed under UV light (UV mini spectrum 1240) at 254 and $366 \mathrm{~nm}$ wavelength. The appearance spot on the plate was calculated retardation factor $\left(\mathrm{R}_{\mathrm{f}}\right)$ with Equation 2 [12].

$$
\text { Retardation Factor }\left(\mathrm{R}_{\mathrm{f}}\right)=\frac{\text { Distance traveled by solute }}{\text { Distance traveled by solvent }}
$$

\subsection{Effect of Fermentation Time on Antioxidant Activity}

The antioxidant activity of FD extract was determined by various fermentation times $(3,5,7,10,14$, and 21 days). FD extract was dissolved in methanol and then the extract $(2 \mathrm{~mL}$ ) was added $2 \mathrm{~mL}$ DPPH $0.02 \%$ (in methanol). The positive control for this assay was quercetin. The samples were incubated for 30 minutes in a dark condition at room temperature and the absorbance was measured using UV-Vis Shimadzu UV mini 1240 at $517 \mathrm{~nm}$. The measurement of the absorbance was conducted two times of repetition [12]. Antioxidant activity was measured following Equation 1.

\subsection{Cytotoxic Assay of Fungal Extract}

Anticancer activity on breast cancer cells MCF-7 was evaluated by AlamarBlue method. MCF-7 cell lines were cultured in DMEM with $10 \% \mathrm{FBS}$. Cells were grown at $37^{\circ} \mathrm{C}$ with $95 \%$ humidity and $5 \% \mathrm{CO}_{2}$ for 3 days until the cell culture reached a density of $60-70 \%$ in a 96-well plate. The initial media was discarded and then replaced with a new medium and reincubated for 24 hours. The cell cultures were then washed with PBS 1-2 times and suspended using a trypsin-EDTA solution and added with a new media. The cell line of $100 \mu \mathrm{L}$ in the plate was added with $10 \mu \mathrm{L}$ of samples (FD extract) with various concentrations $(0.1 ; 0.3 ; 1 ; 3 ; 10 ; 30 \mathrm{~g} / \mathrm{mL})$, and then incubated for 24 hours at $37^{\circ} \mathrm{C}$. The staining process was carried out by adding a solution of AlamarBlue and incubating it for 4 hours. The color intensity of the resulting cells was measured using an Elisa plate reader at a wavelength of $560 \mathrm{~nm}$ (excitation) and $590 \mathrm{~nm}$ (emission). Percent inhibition is calculated as follows Equation 3 [13].

$$
\% \text { Inhibition }=100-\% \text { Viability }=100-\left(\frac{\text { fluorescence of sample -fluorescence of media }}{\text { fluorescence of control cell-fluororescnce of control media }} \times 100\right)
$$

\subsection{Fourier-Transform Infra-Red (FTIR) Spectroscopy Analysis}

One milligram of the fungal extract was crushed with potassium bromide until homogeneous and then compressed to form a transparent pellet with a thickness of $1 \mathrm{~mm}$ using a hydraulic pressing. The pellet was analyzed using an IR instrument (Shimadzu, Japan) at 400-4.000 $\mathrm{cm}^{-1}$ wavenumbers [14].

\subsection{Liquid Chromatography-Mass Spectroscopy (LC-MS) Analysis}

As much as $1 \mathrm{mg}$ of fungal extract was dissolved in a methanol solvent. The sample $(20 \mu \mathrm{L})$ was injected into LCMS (Acquity UPLC, Waters, USA) with ESI (Electrospray lonisation) system of positive ion model, superco C8 column (50 mm in length, $15 \mathrm{~mm}$ in inner diameter), $1.8 \mu \mathrm{m}$ particle size with flow rate adjusted $0.2 \mathrm{~mL} /$ minutes, and column temperature at $40^{\circ} \mathrm{C}$. The result was presented in the form of LC and MS charts [15].

\section{Result and Discussion}

\subsection{Fermentation of Isolate SKF 15}

The morphology of SKF 15 endophytic fungus can be observed based on mycelium formation and filtrate color. The fungus was grown on a PDB medium showed the appearance of mycelium and changing of filtrate color after 10 days of fermentation (Table 1). The formation of mycelium signified the growth of fungi [16]. PDB medium is a common medium for the cultivation of fungi, mold, and yeast [9]. According to Merlin et al. [17], an incubation period under 10 days produced a minimum quantity of secondary metabolites.

\subsection{Antioxidant Activity of Filtrate and Mycelium Extracts}

The result of antioxidant activity of filtrate and mycelium extracts of endophytic fungus SKF15 using DPPH free radical can be seen in Figure 1. Filtrate and mycelium extracts from static and shake fermentations produced different antioxidant activities. At $200 \mathrm{ppm}$ of DPPH, the highest antioxidant activity was FD extract with $49.36 \%$ inhibition, while the lowest activity was MK extract with $4.31 \%$ inhibition. The fungus secreted secondary metabolites into the medium [18]. In this study, the highest antioxidant activity in the filtrate might correlate to the majority of the existence of secondary metabolites in the filtrate. 
Table 1. Morphology of SKF 15 Fungus after 10 Days of Fermentation

\begin{tabular}{ccccc}
\hline \multirow{2}{*}{$\begin{array}{c}\text { Fermentation } \\
\text { Treatment (Day) }\end{array}$} & \multicolumn{2}{c}{ Mycelium Appearance } & \multicolumn{2}{c}{ Medium Color Changing } \\
\cline { 2 - 5 } & FD & FK & FD & FK \\
\hline 0 & No growth & No growth & Clear yellow & Clear yellow \\
\hline 3 & White fibers & No growth & Clear yellow & Clear yellow \\
\hline 5 & $\begin{array}{c}\text { Thin mycelium } \\
\text { formation }\end{array}$ & $\begin{array}{c}\text { Thin fiber } \\
\text { formation }\end{array}$ & Slightly cloudy & Cloudy yellow \\
\hline 7 & $\begin{array}{c}\text { Thin mycelium } \\
\text { covers the } \\
\text { medium surface }\end{array}$ & $\begin{array}{c}\text { White fiber } \\
\text { spreading }\end{array}$ & Cloudy yellow & Cloudy yellow \\
\hline 10 & Thin mycelium & $\begin{array}{c}\text { Mycelium } \\
\text { formation }\end{array}$ & Turbid yellow & Turbid yellow \\
\hline
\end{tabular}

"FD" referred to static fermentation and "FK" referred to shake fermentation

The antioxidant activity of filtrate extract was greater than that of mycelium extract indicating that the antioxidant compound was more abundant in the filtrate (extracellular) than in the mycelium (intracellular). The antioxidant compound in the filtrate extract was produced during the fermentation process by SKF 15 fungus. The metabolites in the filtrate were extracellular metabolites composed of metabolic products such as polysaccharides, proteins, and secondary metabolites [18].

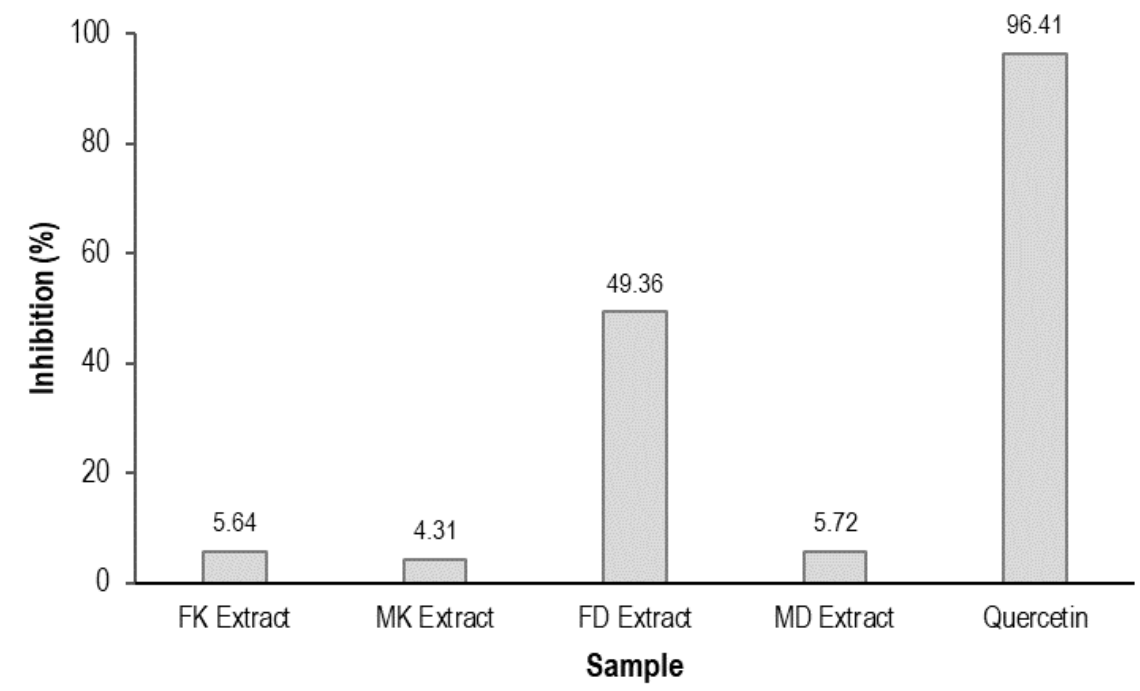

Figure 1. Antioxidant activity of SKF 15 fungus extract-treated by static and shake fermentation. FK: Filtrate from shake fermentation; MK: Mycelium from shake fermentation; FD: Filtrate from static fermentation, and MD: Mycelium from static fermentation.

Types of fermentation affected the antioxidant activity of sample extracts. In this study, the static fermentation was better than the shake fermentation treatment to produce antioxidant compounds. Isolate SKF 15 might be an anaerobic fungus, where oxygen is transferred only through the surface of the medium, so the oxygen transfer is not excessive in the static fermentation. Meanwhile, the shaking process in the shake fermentation causes the size of the air bubbles to become smaller so that the transfer of oxygen becomes greater into the surface area. Fungi have the ability to produce secondary metabolites in different ways [18].

The fermentation treatment of fungi samples gave different results on antioxidant activity. Types and characteristics of bioactive compounds produced by fungi are influenced by types of fermentation treatment. Srikandace et al. [19] researched that Aspergillus sp. endophytic isolates from Seroja Kol marine biota contained the highest antioxidant activity resulting from shake fermentation (71.98\% inhibition). Artanti et al. [7] studied the antioxidant activity of endophytic fungus Taxus sumatrana resulting in $79.5 \%$ inhibition from the static fermentation. Hence, the SKF 15 isolate may have the same properties as a fungus from Artanti's research. 


\subsection{Autographic Assay of Antioxidant Activity}

Antioxidant activities of SKF 15 filtrate extract and quercetin on TLC were marked by a color change on the TLC plate. Quercetin was used as a standard because the compound was known to have antioxidant activity [20]. The mobile phase used is chloroform:methanol (10:1) because the mixture of both solvents provided the best elution based on several experiments with varying ratios. Based on Figure 2., a yellow spot after spraying with DPPH indicated the existence of antioxidant compounds. This is in line with research conducted by Azizah [21] stated fading of purple color and formation of a yellow spot after reaction to DPPH indicates the presence of antioxidant compounds from the sample extract. According to Molyneux [12], an antioxidant compound can donate its hydrogen atom to bind to DPPH characterized by the increasing loss of purple to pale yellow.

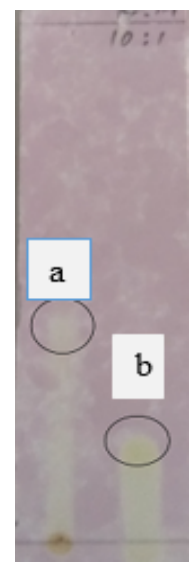

Figure 2. TLC-DPPH free radical scavenging activity of (a) FD extract and (b) quercetin (standard).

The value of the Retardation factor $\left(\mathrm{R}_{\mathrm{f}}\right)$ was used to find out the component in the extract to be compared with quercetin. The $R_{f}$ value of FD extract and quercetin was 0.26 and 0.18 , respectively (Figure 2 ). The $R_{f}$ value indicated the presence of a compound in the sample. According to Gandjar and Rohman [22], the mobile phase must be arranged to form a spot with an $R_{f}$ value between 0.2-0.8 to maximize the elution process. Other compounds in the extract resulted in different $R_{f}$ values [23]. Several factors caused changing of the $R f$ value such as temperature, eluent, and the amount of spotted sample [24]. Therefore, the $R_{f}$ value was unreliable for the identification of the compound so further testing was necessary.

\subsection{Effect of Fermentation Time on Antioxidant Activity of Fungal Extract}

Static fermentation was performed to measure the effect of fermentation time on the antioxidant activity of SKF 15 filtrate (FD) extract. Variation of fermentation time was $3,5,7,10,14$, and 21 days. The results showed that fermentation time influenced the antioxidant activity of FD extract.

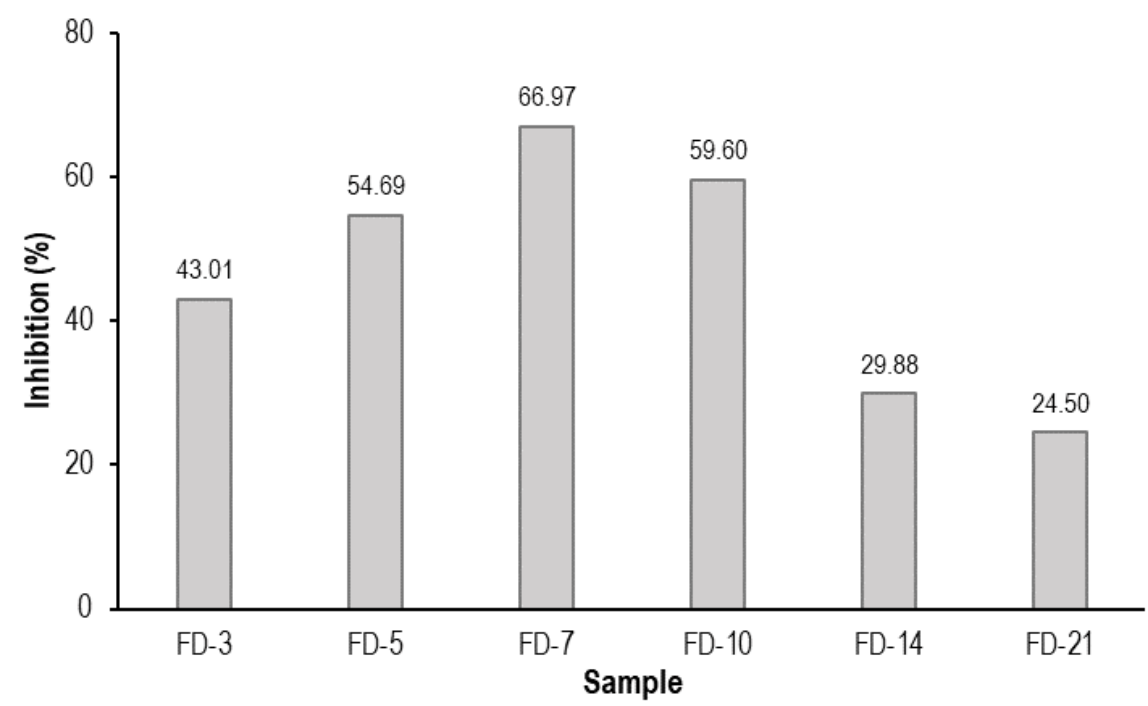

Figure 3. Effect of variation of fermentation time of SKF 15 filtrate (FD) extract. 
As can be seen in Figure 3 that antioxidant activity increased gradually from 3-5 days of fermentation in which at the periods, the fungus was in the adaptation phase. The fungus entered the logarithmic phase with the highest antioxidant activity (66.97\% inhibition) after 7 days. Afterward, the antioxidant activity decreased slowly up to 21 days of fermentation with inhibition of $24.50 \%$. Fungi need adaptation time until day 6 and the growth increases up to day 10 for the logarithmic phase [25]. Factors supporting various antioxidant activities for fungal growth are medium (substrate), temperature, light, $\mathrm{pH}$, and humidity [26].

\subsection{Cytotoxic Assay of Fungal Extract}

In vitro cytotoxic assay is a method to predict the presence of toxic compounds from a sample. In this study, a cytotoxic assay was carried out on breast cancer cells MCF-7. This result was coupled with antioxidant activity to determine whether FD extract has both activities against breast cancer cells. Percentage of inhibition of cytotoxic activities of FD extract from SKF 15 fungus displayed in Figure 4. The FD extract inhibited strongly on breast cancer cells MCF-7 after 3 days of fermentation with the highest cytotoxic activity $81.13 \%$. The cytotoxic activity of FD extract was not in line with SKF 15 fungal growth based on the variation of fermentation time.

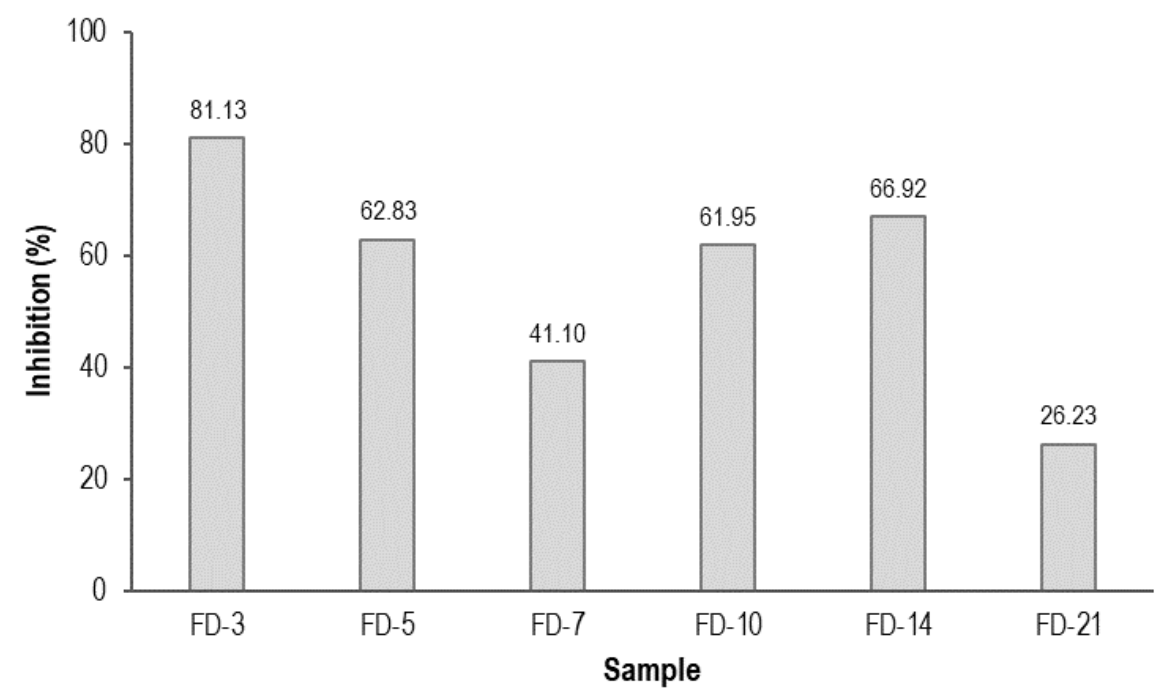

Figure 4. Effect of fermentation time variation on cytotoxic activities.

Based on antioxidant and cytotoxic properties, FD extract has the highest inhibition in 7 days after fermentation for antioxidant activity (Figure 3 ) and 3 days after fermentation for cytotoxic activity (Figure 4). It can be assumed that FD extract contained antioxidant and cytotoxic compounds in which they were generated at different times of fungal growth. Synergistic and antagonistic effects could happen in the FD extract as a crude extract that consisted of various compounds. According to Srikandance et al. [19], endophytic caps have the ability to produce different metabolite compounds.

Scott et al. [27] studied marine natural products such as rigidin, an aromatic compound with pyrrole core, isolated from tunicate with promising selective anti-proliferative activity against cancer and lamellarin, pyrrole alkaloids potential as an anticancer and cytotoxic compound to various tumors. In another research from Wong et al. [28], one of the endophytic fungi isolated from brown seaweed has correlated to Botrydiplodia sp. After 60 days of static fermentation, the fungus secreted an anticancer compound, dihydromyricetin, which was also an antioxidant agent. This showed that each endophytic fungi produced different compounds responsible for different activities.

\subsection{FTIR analysis}

FTIR analysis of FD extracts showed several peaks in certain wavenumbers (Figure 5). The peak at $3452.58 \mathrm{~cm}^{-1}$ indicated the presence of a primary hydroxy group $(\mathrm{O}-\mathrm{H})$. The peak at $1716.65 \mathrm{~cm}^{-1}$ revealed the presence of a carbonyl group $\mathrm{C}=0$ (aldehydes, ketones, carboxylic acids, esters), while the peak at $1230.58 \mathrm{~cm}^{-1}$ referred to the hydroxyl group C$\mathrm{OH}$ (alcohol). Based on the FTIR analysis, FD extract of SKF 15 fungus was confirmed as a phenolic compound containing aromatic group, hydroxy group, and carbonyl.

\subsection{LC-MS analysis}

LC-MS was used to identify the peak area, molecular weight, and compound structure of a sample. Data processing on LC-MS used online databases such as MassBank (https://massbank.eu/MassBank/) and ChemSpider (http://www.chemspider.com/). The LC-MS analysis of FD extract of SKF 15 fungus detected one peak with a retention time 
of $2.15 \mathrm{~min}$ with a candidate mass (m/z) 305 (Figure 6) Based on the online database, it was predicted as dihydroquercetin which has a value of $[\mathrm{M}+\mathrm{H}]^{+}$of 305 , and it meant that the compound could have a molecular weight of $\mathrm{m} / \mathrm{z} 304$.

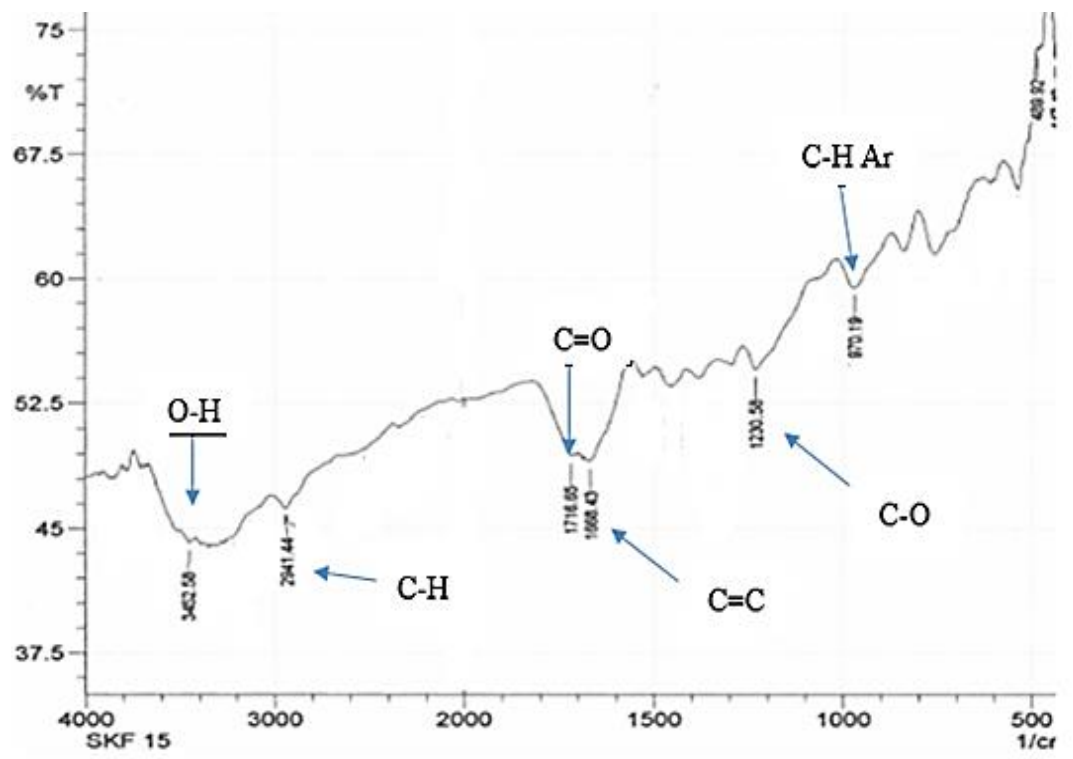

Figure 5. FTIR spectra of filtrate extract (FD extract) of SKF 15 fungus.

Table 2. Characteristics of Absorption Peaks of FD Extract using FTIR Analysis

\begin{tabular}{cccc}
\hline & Wavenumber $\left(\mathbf{c m}^{-1}\right)$ & $\begin{array}{c}\text { Estimation of } \\
\text { Functional Group }\end{array}$ \\
\cline { 1 - 3 } FD Extract & Catauro et al. [29] & Skoog et. al. [30] & O-H \\
\hline 3452.58 & 3448 & $3500-3200$ & C-H \\
2941.44 & - & $2970-2850$ & C=O \\
1716.65 & 1720 & $1760-1690$ & $\mathrm{C}=\mathrm{C}$ \\
1668.43 & 1610 & $1680-1610$ & $\mathrm{C}-\mathrm{H}$ aromatic \\
970.17 & - & $650-995$ & $\mathrm{C}-\mathrm{O}$ \\
1230.58 & - & $1300-1050$ & \\
\hline
\end{tabular}
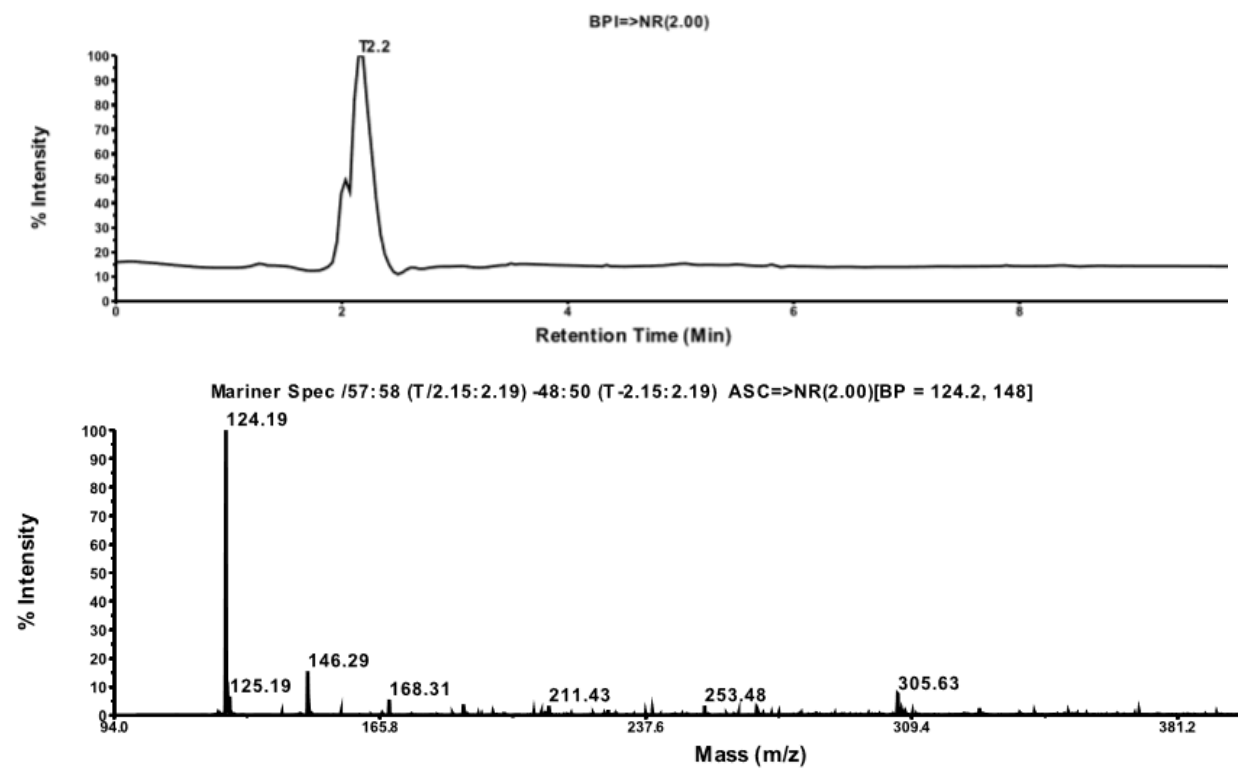

Figure 6. Analysis results of LC-MS of FD extract from SKF 15 fungus (a) LC chromatogram, and (b) MS spectrum.

MS fragmentation of extract was compared to the MassBank database shown in Table 3. The spectrum of fragmentation mass of FD extract was similar to the fragmentation pattern of dihydroquercetin from MassBank Database 
and Abad-Garcia research [31]. It can be predicted that FD extract contained dihydroquercetin compound. The pattern of fragmentation of dihydroquercetin can be seen in Figure 7.

Table 3. Comparison of Fragmentation of FD Extract and MassBank Database

\begin{tabular}{cccc}
\hline $\begin{array}{c}\text { Number of lon } \\
\text { Product }\end{array}$ & \multicolumn{3}{c}{ Mass of Product lon of Dihydroquercetin,[M+H], (m/z) } \\
\cline { 2 - 4 } & FD Extract & MassBank Database & Abad-Garcia et al. [31] \\
\hline 1 & 305.63 & 305.05 & 304,30 \\
2 & 253.48 & 255.05 & 255,80 \\
3 & 211.44 & 212.06 & 212,80 \\
4 & 168.31 & 167.01 & 166,70 \\
5 & 146.29 & 149.02 & 149,00 \\
6 & 124.19 & - & 123,10 \\
\hline
\end{tabular}<smiles>CC(C)CCO</smiles>

$\mathrm{m} / \mathrm{z}: 305$<smiles>Cc1ccccc1C1Oc2cccc(O)c2C(=O)C1O</smiles>

$\mathrm{m} / \mathrm{z}: 253$<smiles>C1CC1</smiles><smiles>O=CC(O)=Cc1ccccc1</smiles><smiles>Oc1ccccc1/C=C/c1ccccc1</smiles>

$\mathrm{m} / \mathrm{z}: 211$<smiles>CCc1ccccc1O</smiles>

Figure 7. Fragmentation pattern of dihydroquercetin.

Ghareeb et al. [32] examined the potential for free radical capture and cytotoxic activity of phenolic compounds from Tectona grandis Linn. The plant has biological activities as antioxidants and anticancer, and one compound was responsible for the activities was dihydroquercetin. The dihydroquercetin captured free radicals by hydrogen transfer. The orthodihydroxy ring of benzene is an activation group that enhances the ability of dihydroquercetion to transfer hydrogen atoms and then improves the antioxidant properties [33,34]. Dihydroquercetin can prevent the formation of free radicals and is widely used in the food and medicine industries $[35,36]$.

\section{Conclusion}

Extracts of SKF 15 endophytic fungus after 10 days of fermentation by static and shake treatments gave varied antioxidant activity. At 200 ppm of DPPH, FD extract showed the highest antioxidant activity with $49.36 \%$ inhibition, while MK extract presented the lowest antioxidant activity with $4.31 \%$ inhibition. Cytotoxic activity against MCF-7 cell lines revealed $63.36 \%$ inhibition from FD extract after 3 days fermentation as the highest activity. Based on FTIR and LCMS analyses, FD extract of SKF 15 fungus might consist of hydroquercetin responsible for antioxidant activity.

\section{Acknowledgment}

Thanks to the Head of the Indonesian Institute of Science (LIPI), Research Center for Chemical, Puspitek Serpong which has provided fund and facilities assistance in this research. 


\section{References}

[1] D.S. Arora \& P. Chandra, "Assay of Antioxidant Potential of Two Aspergillus Isolates by Different Methods Under Various Physio-Chemical Conditions," Brazilian Journal of Microbiology, vol. 41, no. 3, pp. 765-777, 2010.

[2] G. Zdunic, D. Godjevac, K. Savikin, \& S. Petrovic, "Comparative Analysis of Phenolic Compounds in Seven Hypericum Species and Their Antioxidant Properties," Natural Product Communications, vol. 12, no. 11, pp. 1805-1811, 2017.

[3] A. Francini \& L. Sebastiani, "Phenolic Compounds in Apple (Malus $x$ domestica Borkh.): Compounds Characterization and Stability during Postharvest and after Processing". Antioxidants, vol. 2, pp. 181-193, 2013.

[4] A. M. Calvo \& J. W. Cary, "Association of Fungal Secondary Metabolism and Sclerotial Biology," Frontiers in Microbiology, vol. 6, no. 62, pp. 1-16, 2015.

[5] R. F. W. Putrie, I. N. P. Aryantha, Iriawati, \& S. Antonius, "Diversity of Endophytic and Rhizosphere Bacteria from Pineapple (Ananas comosus) Plant in Semi-arid Ecosystem," Biodiversitas, vol. 21, no. 7, pp. 3084-3093, 2020.

[6] A. L. Leitão \& F. J. Enguita, "Fungal Extrolites as a New Source for Therapeutic Compounds and as Building Blocks for Applications in Synthetic Biology," Microbiological Research, vol. 169, no. 9-10, pp. 652-665, 2014.

[7] N. Artanti, S. Tachibana, L. B. S. Kardono, \& H. Sukiman, "Screening of Endophytic Fungi Having Ability for Antioxidant and a-Glucosidase Inhibitor Activities Isolated from Taxus sumatrana," Pakistan Journal of Biological Sciences, vol. 14, no. 22, pp. 1019-1023, 2011.

[8] A. Pidroni, B. Faber, G. Brosch, I. Bauer, \& S. Graessle, "A Class 1 Histone Deacetylase as Major Regulator of Secondary Metabolite Production in Aspergillus nidulans," Frontiers in Microbiology, vol. 9, no. 2212, pp. 1-18, 2018.

[9] M. J. Pelczar \& E.S.C. Chan, Dasar-Dasar Mikrobiologi. Jakarta: UI Press, 2008.

[10] Amirullah, Sartini, \& F. Nainu, "Fungi Endofit dari Tanaman Secang (Caesalpinia sappan L.) Sebagai Penghasil Senyawa Antioksidan," Jurnal Farmasi Galenika, vol. 5, no. 1, pp. 26-32, 2019.

[11] G.-C. Yen \& H.-Y. Chen, "Antioxidant Activity of Various Tea Extract in Relation to Their Antimutagenicity," Journal of Agricultural and Food Chemistry, vol. 43, pp. 27-32, 1995.

[12] P. Molyneux, "The Use of Stabel Free Radical Diphenylpicrylhyddrazyl (DPPH) for Estimating Antioxidant Activity". Songklanakarin Journal of Science and Technology, vol. 26, no. 2, pp. 211-219, 2004.

[13] T. Kiso, Y. Usuki, X. Ping, K.- I. Fujita, \& M. Taniguchi, "L-2,5 Dihydrophenylalanine, an Inducer of Cathepsindependent Apoptosis in Human Promyelocytic Leukemia Cells (HL-60)," The Journal of Antibiotics, vol. 54, no. 10, pp. 810-817, 2001.

[14] D. S. Wibowo "Isolasi dan Karakterisasi Senyawa Antioksidan Kulit Buah Naga (Hylocereus undatus)," Skripsi, Universitas Islam Negeri Syarif Hidayatullah, Jakarta, 2013.

[15] F. Cuyckens \& M. Claeys, "Optimization of a Liquid Chromatography Method Based on Simultaneous Electrospray Ionization Mass Spectrometric and Ultraviolet Photodiode Array Detection for Analysis of Flavonoid Glycosides," Rapid Communications in Mass Spectrometry, vol. 16, pp. 2341-2348, 2002.

[16] I. G. Roosheroe, W. Sjamsuridzal, \& A. Oetari, Mikologi: Dasar dan Terapan. Jakarta: Yayasan Pustaka Obor Indonesia, 2006.

[17] J. N, Merlin, N. Christhudas, P. P. Kumar, \& P. Agastian, "Optimization of Growth and Bioactive Metabolite Production: Fusarium solani," Asian Journal of Pharmaceutical and Clinical Research, vol. 6, no. 3, pp. 98-103, 2013.

[18] N. D. Fajarningsih, M. Nursid, \& E. Chasanah, "Isolasi, Identifikasi, dan Optimasi Produksi Emestrin B dari Kapang Laut Emericella nidulans," dalam Prosiding Seminar Hasil Penelitian Terbaik 2013, Balai Penelitian dan Pengembangan Kelautan dan Perikanan, 2013, pp. 1-15.

[19] Y. Srikandace, Y. Hapsari, \& P. Simanjuntak, "Seleksi Mikroba Endofit Curcuma zedoria dalam Memproduksi Senyawa Kimia Antimikroba," Jurnal IImu Kefarmasian Indonesia, vol. 5, no. 2, pp. 77-84, 2007.

[20] A. K. R. Purba, Mustofa, \& I. Astuti, "Synergistic Interaction between Quercetin and Doxorubicin on Human Breast Cancer Cell Line," Journal of the Medical Sciences, vol. 45, no. 3, pp. 120-126, 2013.

[21] S. K. Azizah, "Aktivitas Antioksidan Ekstrak Isolat-Isolat Kapang dari Tanaman Mangrove Avicennia sp.," Skripsi, Universitas Islam Negeri Syarif Hidayatullah, Jakarta, 2013.

[22] I. G. Gandjar \& A. Rohman, Kimia Farmasi Analisis. Yogyakarta: Pustaka Pelajar, 2007.

[23] C. Lasmaria, "Antioksidan yang Dihasilkan Kapang Aspergillus spp. dan Pengaruhnya terhadap Perbaikan Jaringan Hati Tikus (Rattus novegicus L) Galur Sprague Dawley," Tesis, Universitas Indonesia, Depok, 2011.

[24] T. Robinson, Kandungan Organik Tumbuhan Tinggi. Bandung: ITB Press, 1995.

[25] R. J. Gomes, M. F. Borges, M. F. Rosa, R. J. H. Castro-Gómez, \& W. A. Spinosa, "Acetic Acid Bacteria in the Food Industry: Systematics, Characteristics and Applications," Food Technology and Biotechnology, vol. 56, no. 2, pp. 139151, 2018.

[26] S. Abraham, A. Basukriadi, S. Pawiroharsono, \& W. Sjamsuridzal, "Insecticidal Activity of Ethyl Acetate Extracts from Culture Filtrates of Mangrove Fungal Endophytes," Mycobiology, vol. 43, no. 2, pp. 137-149, 2015. 
[27] R. Scott, M. Karki, M. R. Reisenauer, R. Rodrigues, R. Dasari, W. R. Smith, S. C. Pelly, W. A. L. van Otterlo, C. B. Shuster, S. Rogelj, I. V. Magedov, L. V. Frolova, \& A. Kornienko, "Synthetic and Biological Studies of Tubulin Targeting C2-Substituted 7-Deazahypoxanthines Derived from Marine Alkaloid Rigidins," ChemMedChem, vol. 9, no. 7, pp. 1428-1435, 2014.

[28] C. Wong, P. Proksch, L. T. Tan, S. Lihan, A. Mujahid, \& M. Müller, "Isolation, Identification and Screening of Antimicrobial Properties of the Marine-Derived Endophytic Fungi from Marine Brown Seaweed," Microbiology Indonesia, vol. 9, no. 4, pp. 141-149, 2015.

[29] M. Catauro, F. Papale, F. Bollino, S. Piccolella, S. Marciano, P. Nocera, \& S. Pacifico, "Silica/quercetin Sol-Gel Hybrids as Antioxidant Dental Implant Materials," Science and Technology of Advanced Materials, vol. 16, no. 035001, 2015.

[30] D. A. Skoog, F. J. Holler, \& T. A. Nieman, Principles of Instrumental Analysis Edisi 5. Philadelphia: Saunders College Pub., 1998.

[31] B. Abad-García, S. Garmón-Labato, L. A. Berrueta, B. Gallo, \& F. Vicente, "A Fragmentation Study of Dihydroquercetin using Triple Quadrupole Mass Spectrometry and its Application for Identification of Dihydroflavonols in Citrus Juices," Rapid Communications in Mass Spectrometry, vol. 23, pp. 2785-2792, 2009.

[32] M. A. Ghareeb, H. A. Shoeb, H. M. F. Madkour, L. A. Refahy, M. A. Mohamed, \& A. M. Saad, "Radical Scavenging Potential and Cytotoxic Activity of Phenolic Compounds from Tectona grandis Linn," Global Journal of Pharmacology, vol. 7, no. 4, pp. 486-497, 2013.

[33] K. E. Heim, A. R. Tagliaferro, \& D. J. Bobilya, "Flavonoid Antioxidants: Chemistry, Metabolism and Structure-Activity Relationships," The Journal of Nutritional Biochemistry, vol. 13, no. 10, pp. 572-584, 2002.

[34] Z.-Y. Cai, M. Sun, J. Xing, Q. Luo, \& H. Corke, "Structure-Radical Scavenging Activity Relationships of Phenolic Compounds from Traditional Chinese Medicinal Plants," Life Sciences, vol. 78, no. 25, pp. 2872-2888, 2006.

[35] Y. O. Teselkin, I. V. Babenkova, V. K. Kolhir, A. I. Baginskaya, N. A. Tjukavkina, Y. A. Kolesnik, I. A. Selivanova, \& A. A. Eichholz, "Dihydroquercetin as a Means of Antioxidative Defence in Rats with Tetrachloromethane Hepatitis," Phytotheraphy Research, vol. 14, no. 3, pp. 160-162, 2000.

[36] P. Trouillas, C. Fagnère, R. Lazzaroni, C. Calliste, A. Marfak, \& J.-L. Duroux, "A Theoretical Study of the Conformational Behavior and Electronic Structure of Taxifolin Correlated with the Free Radical-Scavenging Activity," Food Chemistry, vol. 88, no. 4, pp. 571-582, 2004. 